\title{
Situation-based and Cooperative Learning in an Upper-division Fruit Production and Physiology Course
}

Anita $\mathrm{N}$ ina Azarenko ${ }^{1}$

AdDitional INDEX WORDS. case studies, problem-based learning

Summary. A situation-based or modified case study approach to learning has been adopted in an upper division fruit production course that is taught at $O$ regon State $U$ niversity in the D epartment of H orticulture. A new case study, which will have a high probability of generating discussion on key pomological themes, is developed each term. On the first meeting day of class, students identify relevant themes in the case study. A modified jigsaw cooperative learning strategy is then used to cover the relevant subject matter throughout the term. While using this strategy, groups of two to three students become experts on a theme and are responsible for sharing their knowledge with their peers. The instructor mentors the experts by reviewing assignments created by them, checking answers to assignments, and administering quizzes on the themes. A bout midterm, larger groups of six to seven students begin their preparation of an oral presentation and written synthesis of the goals and possible pathways for achieving the targets of the primary stakeholders (i.e., orchardists, field representatives, extension faculty, etc.) that are presented in the case study. The groups make their presentations to the stakeholders at the end of the term. Students are required to prepare an individual written report. This learning approach links theory with practice, gives students practice in extensively analyzing a situation, enables students to become conversant in and knowledgeable of basic pomology, builds positive relationships between fellow students, and provides multiple experiences for communicating information and student's discoveries.

bout $90 \%$ of the graduates from O regon State U niversity's D epartment of $\mathrm{H}$ orticulture become agricultural or landscape practitioners (A. Green, personal communication). A recent survey of $O$ regon employers lists some of the following desirable attributes of potential employees: has knowledge of subject matter, has excellent communication skills both oral and written, works well with others and has good people skills, can teach others, analyzes situations, prepares for multiple outcomes and makes decisions, thinks critically, listens, and works hard. Situation-based, case study and cooperative learning approaches provide excellent opportunities to encourage and/ or enhance the development of these desirable characteristics in undergraduates (Swinton, 1995).

O regon Agricultural Experiment Station technical paper 11609. The cost of publishing this paper was defrayed in part by payment of page charges. U nder postal regulations, this paper therefore must be hereby marked adverti sement solely to indicate this fact.

1Professor, ALS \#4017, D epartment of H orticulture, O regon State U niversity, Corvallis, OR 97331. 
Educational research indicatesthat thinking skills of students are improved by incorporating active learning strategies into the classroom. M cKeachie (1988) stated that student participation, teacher encouragement, and student-to-student interaction improved critical thinking. These activities can be contrasted to other teaching approaches, which allow for only passive listening, and often result in students' cram and erase attitudes and less than desirable learning. The use of more participatory and cooperative learning approaches in the classroom creates a more dynamic environment for individual and group knowledge creation (Johnson et al, 1991).

As a teacher of an upper division fruit production and physiology course, it wasmy responsibility to facilitatelearning of specific subject matter in concert with the development/ enhancement of social and decision-making skills, and higher level reasoning and analysis. The activities in my course target the attributes that are needed to enhance the opportunity for success of students in their future.

\section{Course design}

O regon State U niversity is on a 10-week quarter system. Thefruit production and physiology course is an upper-division course that meets three times a week for $1 \mathrm{~h}$ and has one 3-h laboratory. This is an elective upperdivision course that satiffies an integrative learning course requirement.

A number of challenges exist in designing thiscourse. Thesechallenges include the following:

- Studentshavelittleexposureto fruit production issues prior to this class.

- M any students cannot distinguish an apple tree (Malus $\times$ domestica Borkh.) from a pear tree (Pyrus communis L.).

- M ost students are not familiar with the language of fruit production and physiology.

Because of thesechallenges, many topics can be covered only briefly or not at all. In order for students to achievetheexpected courseoutcomes, I discovered that I had to stimulate enthusiasm for acquiring knowledge quickly and intensively. Additionally, I needed to create a classroom environment conducive to this goal.

I have found that when students have ownership of the learning process, havetheopportunity to link theory with

\section{C ase Study: Tygh Valley-N ew Orchard G round?!}

August 1997, Preston lets out a great sigh; he has completed the deer fencing of his newly acquired 240-acre (97 ha) piece of land in Tygh Valley. H e reflects on the family's plans for the development of this new orchard site. The ground is located about 33 miles $(53 \mathrm{~km})$ south of The Dalles at an elevation of about $1600 \mathrm{ft}(480 \mathrm{~m})$. The view is spectacular with Three-mile C reek bordering the southern portion of the property at the base of a 200-300 ft (60-100 m) ravine. The White River can be seen about a 0.5 miles $(0.8 \mathrm{~km})$ from the southeast corner of the property. M aupin is about 10 miles $(16 \mathrm{~km})$ southeast of this plateau.

Until now, the family business had been exclusively located in Parkdale where the Klingle family owns and manages about 150 acres (60 ha) of orchard. The predominant crop grown at this location has been pears. 'Bartlett' and 'd'Anjou' are the main cultivars planted with 40 acres ( 16 ha) each. 0 ther cultivars include Bosc [15 acres ( 6 ha)], Red d'Anjou [ 20 acres ( 8 ha) ], Forelle [5 acres (2 ha)], Packham's T riumph [10 acres ( 4 ha) ], and Starkrimson [ 4 acres (1.6 ha)]. About 30\%-40\% of the pear acreage consists of trees that are $40+$ years old. Minor acreage of apples ['] onagold' on ' $M$ alling.7EM LA' rootstock, 14 acres (5.6 ha)], and cherries (Prunus avium L.) ['Lapins' on M azzard seedling rootstock, 8 acres ( 3.2 ha)] have recently been planted (third and fourth leaf, respectively). Since Preston'sreturn hometo thefamily farm, thefamily decided it wastime to expand. Where should they go?

Before Preston's return to the family business, after graduating from 0 regon State U niversity, he worked as a foreman for another grower who helped him to discover that there may be other areas into which orchardists could expand that might provide advantages over traditional locations in the mid-Columbia area. Tygh Valley appeared to be one of these. What were the advantages of thislocation?T his area was purported to have less rainfall and temperatures appeared to besimilar to $D$ ufur in thewinter and warmer than Parkdale in the summer. Risk and labor demand could be spread since crop maturation would occur at different times. Pest pressure could be lower. What could make this a bad decision? I s the growing season long enough for late maturing apples? $\mathrm{H}$ ow cold does it get in the winter? What about spring frosts? I s the site too windy? Will the hardpan in the soil limit growth of the fruit crops? $\mathrm{H}$ ow well will the harvest maturity of various crops fit with the availability of labor from the Parkdale operation?

The soil types of the T ygh V alley property are Wapinitia and Watama silt loam. The site slopes downward from the northeast to southeast and appears to be a relatively frost-free site. A couple of low spots may require wind machines in the future to reduce the risk of frost damage. Through about the center of the property, are some seasonal water drainage draws that may pool water during the wet times of the year.

"Spring will be here sooner than I think," says Preston. "Trees have been ordered, enough to plant 10 acres ( 4 ha) of 'Forelle', 10 acres ( 4 ha) of 'Red Anjou', 10 acres ( 4 ha) of 'Bartlett', 8 acres ( 3.2 ha) of 'G ranny Smith', and 2 acres ( 0.8 ha) of ' $G$ ala'. M ost of the pears are grafted onto $\mathrm{O} \mathrm{Id} \mathrm{H}$ ome $x$ Farmingdale $(\mathrm{OH} \times \mathrm{F}) 87$ and $\mathrm{OH} \times \mathrm{F} 97$. Pear trees will be planted on an $8 \times 16 \mathrm{ft}(2.4 \times 4.8 \mathrm{~m})$ spacing in a north to south orientation and trained to a multiple leader tree. Pollinizers will not be planted since cultivars will be alternated every two rows. The ' $G$ ranny Smith' and ' $G$ ala' trees are on ' $G$ eneva 30' (G .30) rootstock. A pple trees will be planted in a north to south orientation also at an $8 \times 16 \mathrm{ft}$ $(2.4 \times 4.8 \mathrm{~m})$ spacing and trained to a central leader. Pollinizers are 'Snowdrift' crabapples (Malus $M$ ill.) and 'Earligold'.

I rrigation lines and pipeare being installed. Water will be ordered from thePine $\mathrm{H}$ ollow I rrigation D istrict and the guaranteed 2 stored acre $\mathrm{ft}\left(2457.2 \mathrm{~m}^{3}\right)$ will be available as of $1 \mathrm{~J}$ une, unless of course there is adrought. I $\mathrm{n}$ future years, if we use up our water allotment by the end of the summer or have a drought, the well that will be dug will provide water, if needed. What type of irrigation system should we use?"

Preston considers, "And we will have only planted a little over $25 \%$ of the acreage this spring! What will we plant in the remaining $110^{+}$acres $\left(44^{+}\right.$ha) ? We need to begin seeing a return on our investment as early as possible. $\mathrm{H}$ igher density pears begin to produce at their maximum potential in 10-12 years. $M$ any of theblocksin Parkdaleweregetting older but are still producing well. $\mathrm{H}$ ere at Tygh Valley, we could begin harvesting earlier and extend the picking season of a particular cultivar. The packinghouse wants our pear fruit." 
“H igher density apple plantingson dwarfing rootstocksare more precociousand begin producing in 4-5 years. If more apples were planted, how intensively should they be planted? Would the trees be free standing or should they be trained to a slender spindle, vertical axis, etc? We haven't been interested in trellising or supporting trees in the past. What rootstock should we use? I know ' $G$.30' is 'M .7EM LA' size but appears to have higher yield efficiency. Should we risk planting this new rootstock in all of our plantings? Should we grow more apples to spread out our risk and fill some of our labor gaps? We could probably ripen a late season variety like 'G ranny Smith' here. But the price of apples has been lousy! A Washington packinghouse would probably take our apples. It may be better to go with a packinghouse that markets predominantly apples not pears like their current packinghouse. A couple of other newer cultivars I have heard about might fit in well. Prices would probably be better for one of these cultivars. What would fruit quality belike? I s it too hot or is the light intensity to o great to get the right type of finish on these later ripening cultivars? What about pollinizers? We' ve had such bad luck with fireblight (Erwinia amylovora (Burrill) Winslow) susceptibility of the 'M anchurian' crabapple."

"Cherries grafted onto new dwarfing rootstocks and planted in higher densities will shift the bearing curve from 6-7 to 3-4 yaers. $\mathrm{N}$ ew late ripening cherry cultivars would fill a gap in labor demand and command a better price than that of the $4 \mathrm{~J}$ uly 'Bing' cherry glut. We'd need to hire more labor during cherry harvest if we planted a significant acreage of cherries. If we plant cherries on dwarfing rootstocks, we would betreading new ground since the rootstocks have only been commercially available for 4-5 years and some only a couple of years. Some of the newer cultivars are self-fertile and could overset, producing small fruit. What happens if these cultivars are put on dwarfing rootstocks? $\mathrm{H}$ ow would he train the trees, central or multiple leader? I f we plant cherries, would the row orientation remain the same? The prevailing wind is from the southwest. R ows running north to south could prevent air drainage in the low spots and increase the risk of frost but east to west rows tend not to have the crop evenly distributed throughout the canopy. The north side usually has less and poorer quality fruit. The research was done on apples and pears, would cherries respond the same way? A wind machine, to reduce the potential for frost damage, would cost about $\$ 15,000$. Would it pay for itself? Some of the poorly drained drawswould probably be less suitable for the dwarfing stocks since they seem to be susceptible to poor growth in wet soils (wet feet sensitive). H ow will the hardpan 6-24 inches $(15-61 \mathrm{~cm}$ ) below the soil impact cherries?"

Currently, the family business employs two full-time guys year round in addition to my father and me. Four additional families live on the properties and work about 10 months of the year from February until the end of $\mathrm{N}$ ovember. Fifteen to twenty other people work from the beginning of August through the beginning of $\mathrm{N}$ ovember. Eventually we would have to provide housing at the Tygh Valley site.

A timeline of activities reveal a requirement for significant labor inputs. Yet, there appear to be some gaps in labor demand. From the time that fruit thinning is completed to the beginning of 'Bartlett' harvest is a big gap. Another gap would be between 'Bartlett' and 'Anjou' harvests. The goal would be not to overlap with Parkdale's harvest of 'A njou' and later ripening pears. However, after the pear harvest, there is another small window coincident with 'Jonagold' and 'G ranny Smith' harvest.

While standing at the site, Preston ponders all these many questions. A decision would have to be made now, since he would have to order trees for planting in 2 years.

What goals/ targets is Preston hoping to achieve? (i.e., early return on his investment, maintain steady labor force)

\section{H ow might Preston achieve these goals?}

Details to consider:

What should Preston do to continue to prepare the site for planting?

What crops and cultivars should he plant? What pollinizers will be used, if needed? Where would you place them?

H ow will the trees be trained? At what spacing should they be planted? What will be the row orientation?

Are wind machines needed?

What type of irrigation system should he install?

What will be the costs of establishment? What year will each alternative achieve a positive cash flow? What year will each alternative pay all previous establishment costs? application, and know that their discoveries and insights are valued and meaningful, they develop more knowledge. Additionally, the desirable social attributesareacquired or enhanced in this relatively short period of time. To this end, I have chosen a situation-based approach (modified case study) to link theory with practice. D uring the learning process, I involvestakeholders(e.g., orchardists, field representatives, extension faculty, researchers, etc.), who are described in the casestudy and who may be impacted by the decisions made. Also, I expect the students to present multiple pathways in addressing the dilemma faced by the horticultural practitioners.

A new casestudy isprepared before each term. I identify key themes I want studentsto explore during theterm and select a situation that has a high probability of generating interest in these themes. I prepare a written description of the situation (see case study below). On the first day of class, students read the case study and are directed to jot down topics in the left margin that, if better understood, would enable them to help the practitioners with their dilemma. After having read thecasestudy, amind map (Buzan, 1983) iscreated on the blackboard of the themes that students determined were important. The students then cluster thetopics. U sually 10-12 main themes emerge from this exercise (Table 1) and these themes are used to create a syllabus for the term. I create and present the syllabus to the students thefollowing class period. The syllabus also includes a list of readings for each theme.

Themodified jigsaw learning strategy (Smith and Waller, 1997) is then used throughout the duration of the term. The class is divided into 9 to 10 groups containing two to three people. Each small group is then assigned a theme, of which they will become experts. The groups are required to prepare a list of 15 to 20 questions about their theme and include their answers. I review, edit and revisethe questionsand answers. Prior to beginning class discussion about the topic, the groups, who are not experts on the theme, receive two to three of these questionsfor their review and completion. Students submit their answersto meat least I $h$ before the class meets again. This step is included to ensure that students read at least some of the material prior to discussing it in class. The groups spend 5 
to 10 min discussing their individual answers and are then asked to write them on the board. The experts, including me, expand, modify and/ or improve upon the answers through the use of visual aids including transparencies, slides and props. A debriefing discussion of the relevance of this themeto the case study helps reinforce the need for the theory and information. A quiz is administered after the completion of each theme.

About half way through the term, larger groups of six to seven studentsare created. A laboratory period of $3 \mathrm{~h}$ is set aside to accomplish four major tasks related to the case study: 1) discuss and

\section{T able 1. Themes that emerged, after reading the case study, during the mind-mapping exercise.}

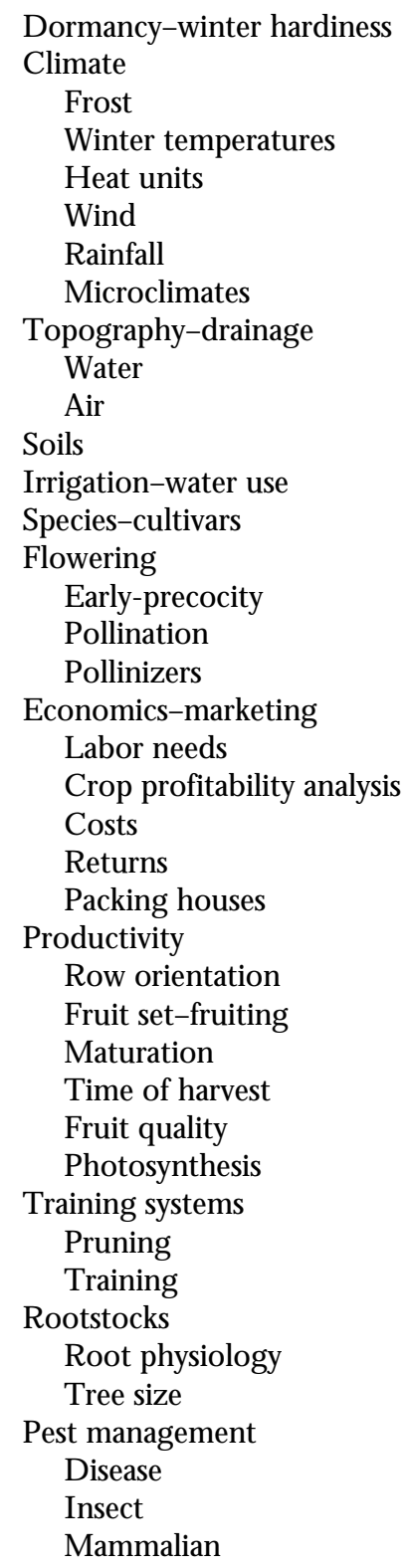

list skills needed within the group in order for them to be successful, 2) develop rulesand goalswithin each group, 3) distribute responsibility for obtaining information on critical issues mentioned within the case study, and 4) establish subsequent meeting times. A total of 6 class hours ( $3 \mathrm{~h}$ of lecture and $3 \mathrm{~h}$ of lab) are set aside for students to work on the case study analysis.

T owards the end of the term, the large groups are required to prepare an oral presentation that synthesizes the goals of the primary stakeholders in the case study (i.e., orchardists, field representatives, extension agents, etc.) and a variety of pathways (at least two) in which the goals or targets may be achieved. As a group, the oral presentation is made to the primary stakeholders. After the presentation of the options, each student must prepare an individual written summary of his/ her conclusions. The findings presented in the written summary do not have to be the same as the group's conclusions. In fact, I encouragethestudentsto modify their individual reports because they have had an opportunity to discover other possible options from the oral presentations from the other groups.

$M$ ost students have found this approach to be highly rewarding. Those primary stakeholders mentioned in the casestudiesthat havelistened to the oral presentations have also stated that they gained new knowledge or insights.

\section{Positive attributes and concerns}

Students, faculty and practitioners have identified many positive attributes with this type of teaching approach. Students discover the relevancy of subject matter and link theory with practice. The multiple iterations throughout the process help students to inculcate knowledge. Positive relationships are created between fellow students. Students make valuable contacts with practitionersand the practitionersoften learn from the students.

Some of the students' concerns or criticismshaveincluded; the classcan be chaotic, group work is frustrating, too much reading is required, depth is lacking in subject matter, and there is too little time spent on a single theme.

\section{Future improvements}

A synthesis of the answers to the expert group questions will be provided either on the World Wide Web
(Web) or in hard copy after discussion of the subject matter and beforea quiz. This synthesis should help alleviate someof the perception of chaos, clarify misunderstandingsand misinterpretations, and add more detail and depth to a particular theme, if necessary.

With respect to the situation-based approach to learning, a more formal discussion on who all thestakeholdersarewill beincorporated. Additionally, morestakeholders will be involved in the final oral presentations. L astly, expectations will be more explicitly defined.

\section{Conclusion}

L earning in the classroom hasbeen enhanced with theincorporation of these more active participation techniques. After having participated in this class, students will have practiced in an extensive analysis of a situation and synthesized possible solutions. They will have practiced interactive and cooperative learning and hopefully developed and/ or refined group skills. Students will havediscovered thesignificanceof theory and how it applies to practice, and are conversant and knowledgeable of basic pomology. They will have had multiple experiences of communicating information and their knowledge.

This approach has worked well for me; however, each class has its own personality. Modifications to the approach will always have to be made to accommodate and facilitate learning in diverse groups.

\section{Literature cited}

Buzan, T. 1983. U se both sides of your brain. D utton, N ew York.

G reen, A. 1999. Personal communication with the undergraduateadvisor of the D ept. H ort., O re. State U niv.

Johnson, D.W., R.T. Johnson, and K.A. Smith. 1991. Active learning: Cooperation in the college classroom. Interaction Book Co., Edina, M inn.

M cK eachie, W. 1988. T eaching thinking. $\mathrm{N}$ ational center for research and improvement of postsecondary teaching and learning update 1:81.

Smith, K.A. and A.A. Waller. 1997. Cooperative learning for new teachers. I n: W.E. Campbell and K.A. Smith (eds.). N ew paradigms for college teaching. Interaction Book Coo., Edina, M inn.

Swinton, S.M . 1995. T eaching and learning with cases-Promoting active learning in agriculture, food and natural resource education. M ich. State U niv., East L ansing. 